\title{
West Nile Virus: An Overview of its Recent Spread in the Mediterranean Basin
}

\author{
Ahmed Tabbabi ${ }^{1 *}$, Sajida Sboui ${ }^{2}$ and Jabeur Daaboub ${ }^{1}$ \\ ${ }^{1}$ Department of Hygiene and Environmental Protection, Ministry of Public Health, Tunisia \\ ${ }^{2}$ Faculty of Medicine of Monastir, Monastir University, Monastir, Tunisia
}

*Corresponding author: Tabbabi A, Department of Hygiene and Environmental Protection, Ministry of Public Health, Tunisia, Tel: + 0021697085424; E-mail: tabbabiahmed@gmail.com

Received date: September 16, 2017; Accepted date: October 26, 2017; Published date: November 06, 2017

Copyright: (C) 2017 Tabbabi A, et al. This is an open-access article distributed under the terms of the Creative Commons Attribution License, which permits unrestricted use, distribution, and reproduction in any medium, provided the original author and source are credited.

\begin{abstract}
West Nile virus (WNV) is transmitted to humans through infected Culex mosquito. It causes a sudden fever, but also, more rarely, neuroinvasive infections. Since its first identification in East Africa, the virus has been identified on all continents. The subject of this article was to review its spread in the Mediterranean basin until recently. It is very important for the implementation and development of control strategies to minimize risk of WNV emergence in the Mediterranean basin. Available data were used to assemble and synthesize information. West Nile virus has become endemic/enzootic in Eastern Europe and the Mediterranean basin. In other regions such as the South of France, Portugal and the Maghreb, the virus causes sporadic cases in both humans and equidae. Since 2010, there has been an increase in the number of cases, as well as an extent of the endemic area. The endemic area will probably increase in coming decades because of climate change, especially in the north and west, and thus reach previously unharmed areas.
\end{abstract}

Keywords: West Nile virus; Mediterranean basin; Endemic/enzootic; Sporadic; Extension; Risk

\section{Introduction}

West Nile virus is an arbovirus transmitted by blood-borne arthropods in which it multiplies [1]. Its natural cycle of transmission is between mosquitoes and birds. However, this virus can infect many other animal species, in particular, horses and humans [2,3]. Most human and equine cases are asymptomatic. Nevertheless, nearly $30 \%$ of infected persons show symptoms ranging from a simple influenzalike syndrome to an encephalitis syndrome with a lethality rate of $17 \%$, $10 \%$ of infected horses show neurological signs [4-7].

The virus was first isolated in 1937 in the West Nile district of Uganda during research on yellow fever in a 37-year-old woman with a high fever. Subsequent serological tests in humans in Central Africa in 1939 showed the presence of the virus in Congo and Sudan with no associated clinical signs. In 1942 and 1953 it was identified in humans respectively in Egypt and India. In the 1950s, it was found in birds and mosquitoes in Egypt. It was in 1953 that the ecology of the virus was better known and it was not until 1957, during an epidemic in Israel, that it was recognized as a possible cause of meningoencephalitis.

The virus has spread to Europe, causing numerous epidemics and epizootics (Camargue in 1962, 1975, 1980 and 2000, Romania in 1996, Czech Republic in 1997, Italy in 1998, Russia in 1999), then in America (United States in 1999, Mexico in 2003) and Oceania. Since the 1990s, the number and severity of human cases have increased. Currently regarded as re-emerging, it is found in many European countries, notably in Romania, Russia, Italy, Greece but also in Israel, North Africa and the United States.

The aim of this review was to present the status and the evolution of cases in the Mediterranean countries between 2000 and recently. The prediction of epizootics is very difficult because the activity of mosquitoes and therefore the transmission of the virus are highly dependent on the climate but also on the fauna and the geography of the regions.

\section{Spread of West Nile Virus in the Mediterranean Basin}

Introduced on the American continent in 1999, the WNV invaded the United States from east to west in a few years. It is now endemic, and present to the south of Argentina. Between 1999 and 2010, nearly 1.8 million people were infected and more than 12,000 cases of encephalitis and/or meningitis were reported, of which 1,308 were fatal [8].

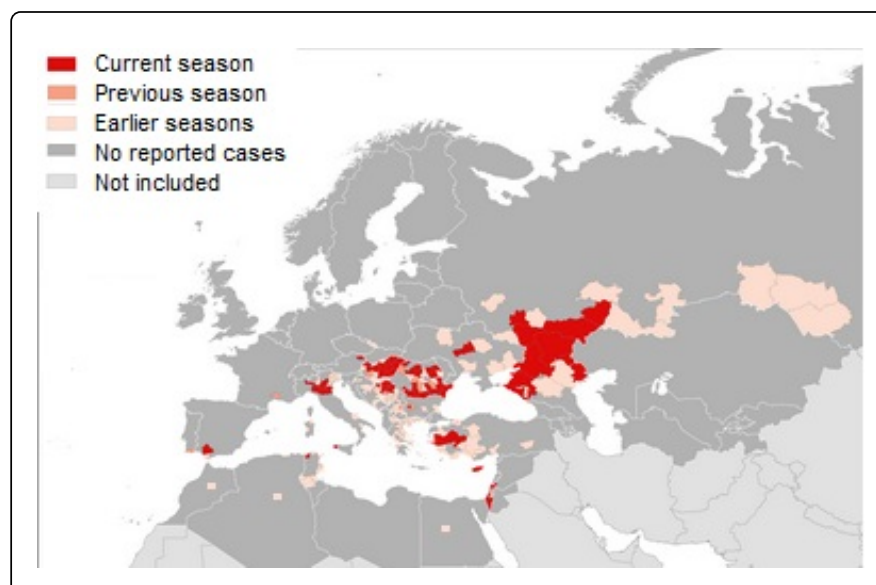

Figure 1: "Spread of west nile virus in the mediterranean basin" section and not in introduction section. 
In Europe, the virus has been reported in the Mediterranean basin since the 1960s, with no significant impact on human or animal health. In fact, human or equine cases were previously caused by the lineage strain 1a and characterized by moderate pathogenicity in humans and horses and very limited or non-existent in wild birds [6]. But the incidence of human and equine neurological cases has increased sharply in the years 2000, especially from 2010 [9]. Moreover, line 2, previously confined to the south of the Sahara, was recently detected in Western and Central Europe [10], (Hungary), Austria, Greece, Italy [11-13]. The major epidemic that erupted in Macedonia and Greece in 2010 was due to this same line [12-14]. The epidemics of summers 2011 and 2012 broke out in the same locations as in 2010 except in Spain, but with an extension to Ukraine, the Balkans, Morocco, Tunisia and Algeria (Figure 1). As in 2010, most cases were detected between the end of July and the end of September. In 2013, Italy, Central Europe (Hungary, Romania, Czech Republic and Serbia), Russia and Tunisia were again affected $[15,16]$.

Most Mediterranean countries have set up surveillance, either passive or active. Nevertheless, epidemics/epizootics remain unpredictable, both in time and space. A previous study showed that excessive temperatures favored their onset [17].

\section{Conclusion}

West Nile virus has been present in Europe and the Mediterranean basin since the beginning of the 21st century. In Eastern Europe and the Mediterranean basin, as well as in Andalusia, the virus has become endemic/enzootic. In other regions such as the South of France, Portugal and the Maghreb, the virus causes sporadic cases in both humans and equidae. Since 2010, there has been an increase in the number of cases, as well as an extent of the endemic area. The affected regions have similar ecological characteristics: a wetland (pond, swamp, stream) near which various migratory avian species live, close to an urban area where mosquitoes of the genus Culex. The climate is Mediterranean to continental with hot summers.

In the coming decades, in view of climate change, it is likely that the endemic area will increase, especially in the north and west, and thus reach previously unharmed areas. The Mediterranean area, close to the endemic area, will certainly be concerned in the years to come.

\section{References}

1. Campbell GL, Marfin AA, Lanciotti RS, Gubler DJ (2002) West Nile virus. Lancet Infect Dis 2: 519-529.
2. Bunning ML, Bowen RA, Cropp B, Sullivan K, Davis B, et al. (2001) Experimental infection of horses with West Nile virus and their potential to infect mosquitoes and serve as amplifying hosts. Ann NY Acad Sci 951: 338-339.

3. Dauphin G, Zientara S, Zeller H, Murgue B (2004) West Nile: Worldwide current situation in animals and humans. Comp Immunol Microbiol Infect Dis 27: 343-355.

4. Rossi S, Ross T, Evans J (2010) West Nile virus. Clin Lab Med 30: 47-65.

5. Sambri V, Capobianchi M, Charrel R, Fyodorova M, Gaibani P, et al. (2013) West Nile virus in Europe: emergence, epidemiology, diagnosis, treatment, and prevention. Clin Microbiol Inf 19: 699-704.

6. Castillo OJ, Wood J (2004) West Nile virus infection of horses. Vet Res 4: 467-483.

7. Gardner I, Wong S, Ferraro G, Balasuriya U, Hullinger P, et al. (2007) Incidence and effects of West Nile virus infection in vaccinated and unvaccinated horses in California. Vet Res 38: 109-116.

8. Kilpatrick A (2011) Globalization, land use, and the invasion of West Nile virus. Science 21: 323-327.

9. https://ecdc.europa.eu/en/west-nile-fever

10. Bakoni T, Hubalek Z, Rudolf I, Nowotny N (2005) Novel flavivirus or new lineage of West Nile virus, central Europe. Emerg Inf Dis 11:225-231.

11. Bakoni T, Ivanics E, Erdelyi K, Ursu K, Ferenczi E, et al. (2005) Lineage 1 and 2 strains of encephalitic West Nile virus, central Europe. Emerg Infect Dis 12: 618-623.

12. Papa A, Politis C, Tsoukala A, Eglezou A, Bakaloudi V, et al. (2012) West Nile virus lineage 2 from blood donor, Greece. Emerg Infect Dis 18: 688-689.

13. Savini G, Capelli G, Monaco F, Polci A, Russo F, et al. (2012) Evidence of West Nile virus lineage 2 circulation in Northern Italy. Vet Microbiol 158 : 267-273.

14. Chaintoutis S, Chaskopoulou A, Chassalevris T, Koehler P, Papanastassopoulou M, et al. (2012) West Nile virus lineage 2 strain in Greece. Emerg Infect Dis $19: 827-829$.

15. Sabatino D, Bruno R, Sauro F, Danzetta M, Cito F, et al. (2014) Epidemiology of West Nile disease in Europe and in the Mediterranean basin from 2009 to 2013. Biomed Res Int 9: 78-92.

16. Rudolf I, Bakonyi T, Sebesta O, Mendel J, Peško J, et al. (2014) West Nile virus lineage 2 isolated from Culex modestus mosquitoes in the Czech Republic, 2013: Expansion of the European WNV endemic area to the North? Euro Surveill 19: 2-5.

17. Paz SM, Green MS, Tsioni G, Papa A, Danis K, et al. (2013) Permissive summer temperatures of the 2010 European West Nile fever upsurge. Plos One 8: e56398. 